Review

\title{
Drug Eluting Stents for Malignant Airway Obstruction: A Critical Review of the Literature
}

\author{
Wolfgang Hohenforst-Schmidt ${ }^{1}$, Paul Zarogoulidis ${ }^{2}{ }^{凶}$, Georgia Pitsiou ${ }^{2}$, Bernd Linsmeier ${ }^{3}$, Drosos Tsavlis ${ }^{2}$, \\ Ioannis Kioumis ${ }^{2}$, Eleni Papadaki², Lutz Freitag, ${ }^{4}$ Theodora Tsiouda ${ }^{2}$, J Francis Turner ${ }^{5}$, Robert Browning 6 , \\ Michael Simoff ${ }^{7}$, Nikolaos Sachpekidis ${ }^{8}$, Kosmas Tsakiridis ${ }^{8}$, Bojan Zaric ${ }^{9}$, Lonny Yarmus ${ }^{10}$, Sofia Baka ${ }^{11}$, \\ Grigoris Stratakos ${ }^{12}$, Harald Rittger ${ }^{1}$ \\ 1. Medical Clinic I, "Fuerth" Hospital, University of Erlangen, Fuerth, Germany. \\ 2. Pulmonary Department-Oncology Unit, “G. Papanikolaou“ 'General Hospital, Aristotle University of Thessaloniki, Thessaloniki, Greece. \\ 3. Department of General Surgery, Coburg Clinic, Coburg, Germany. \\ 4. Department of Interventional Pneumology, Ruhrlandklinik, University Hospital Essen, University of Essen-Duisburg, Tueschener Weg 40, 45239 Essen, \\ Germany. \\ 5. Division of Interventional Pulmonology \& Medical Oncology, Cancer Treatment Centers of America, Western Regional Medical Center, Goodyear, AZ. \\ 6. Pulmonary \& Critical Care Medicine, Interventional Pulmonology, National Naval Medical Center, Walter Reed Army Medical Center, Bethesda, U.S.A. \\ 7. Bronchoscopy and Interventional Pulmonology, Pulmonary and Critical Care Medicine, Henry Ford Hospital, Wayne State University, School of Medicine, \\ MI, USA. \\ 8. Cardiothoracic Surgery Department, “Saint Luke“ Private Hospital, Thessaloniki, Panorama, Greece. \\ 9. Institute for Pulmonary Diseases of Vojvodina, Clinic for Thoracic Oncology, Faculty of Medicine, University of Novi Sad, Serbia. \\ 10. Division of Pulmonary and Critical Care Medicine, Sheikh Zayed Cardiovascular \& Critical Care Tower, Baltimore, U.S.A. \\ 11. Oncology Department, “Interbalkan“ European Medical Center, Thessaloniki, Greece. \\ 12. $1^{\text {st }}$ Respiratory Medicine Department of National University of Athens, "Sotiria" General Hospital Athens, Greece.
}

$\triangle$ Corresponding author: Paul Zarogoulidis, M.D, Ph.D. Pulmonary Department-Oncology Unit, “G. Papanikolaou“ General Hospital, Aristotle University of Thessaloniki, Thessaloniki, Greece. Fax: 00302310992424 Mobile: 00306977271974 E-mail: pzarog@hotmail.com.

() Ivyspring International Publisher. Reproduction is permitted for personal, noncommercial use, provided that the article is in whole, unmodified, and properly cited. See http://ivyspring.com/terms for terms and conditions.

Received: 2015.08.20; Accepted: 2015.11.01; Published: 2016.01.13

\begin{abstract}
Lung cancer being the most prevalent malignancy in men and the $3^{\text {rd }}$ most frequent in women is still associated with dismal prognosis due to advanced disease at the time of diagnosis. Novel targeted therapies are already on the market and several others are under investigation. However non-specific cytotoxic agents still remain the cornerstone of treatment for many patients. Central airways stenosis or obstruction may often complicate and decrease quality of life and survival of these patients. Interventional pulmonology modalities (mainly debulking and stent placement) can alleviate symptoms related to airways stenosis and improve the quality of life of patients. Mitomycin $C$ and sirolimus have been observed to assist a successful stent placement by reducing granuloma tissue formation. Additionally, these drugs enhance the normal tissue ability against cancer cell infiltration. In this mini review we will concentrate on mitomycin $C$ and sirolimus and their use in stent placement.
\end{abstract}

Key words: pharmacology, stents.

\section{Introduction}

Lung cancer still remains a difficult to treat cancer, since patients are diagnosed at late stage disease due to lack of symptoms.[1] Moreover; lung cancer is the second most lethal cancer after prostate for men and breast for women, with a trend to increase for women in the future.[1] Several medical societies are trying to identify those groups of patients that will benefit from imaging screening with several novel techniques.[2-4] Until now there is no algorithm for early diagnostic approach for lung cancer, and patients are usually investigated if symptoms appear. In the last decade several molecular pathways have been investigated and several novel drugs are already on the market for non-small cell lung cancer (NSCLC).[5-8] Regarding small cell lung cancer (SCLC) we still do not have novel therapies, however; 
novel treatment approaches are investigated with the main concept of immunomodulation being the most feasible right now.[9-14] Side effects from non-specific cytotoxic agents are well known and there are several patients that have to postpone their treatment. $[15,16]$ Apart from the side effects induced by the chemotherapeutic agents, there are several situations where the tumor has infiltrated different parts of the airways and respiratory distress is observed.[17] Several techniques can be used to open a closed central airway and chemotherapy or radiotherapy can be used to preserve the result. $[18,19]$ Debulking of cancer tissue is usually performed with different types of lasers, electrocautery, argon plasma coagulation (APC) or cryotherapy.[20] (Figures 1-2) In order to keep the airway opened we use additionally stent devices.[20, 21] Ballon dilatation and photodynamic therapy (PDT) are other options with specific indications [22, 23] There is also a classification system for airway stenosis that can be used by medical practitioners.[24] Stents have been used for tracheal and esophageal fistulas.[25, 26] For malignant airway stenosis we usually use self-expanding covered or uncovered stents. [21] In order to keep the good result of debulking cancer tissue we have to choose carefully the right time of debulking with systemic, intratumoral $[27,149]$ (or a combination of both modalities of) chemotherapy and / or radiotherapy. Moreover; it has been observed that different stents (diameter, length, materials) induce different local stress.[28] Furthermore stents induce locally stress to the sur- rounding tissues. They increase proliferation of granuloma tissue in benign airway stenosis and increase angiogenesis. Cancer tissue which already has increased angiogenesis when more stress is applied locally shows further enhanced tissue formation.[29] Therefore novel cytokine eluting stents are being developed.[30] Furthermore, novel research of stent placement at least for the gastrointestinal tract has indicated that stent placement might induce cancer cell migration.[31] Several drugs have been used as adjuvant local application in order to preserve the airway passage.[30, 32-36] In this review we will focus on the drugs that have been used with stents, their pharmacological activity and future applications. Additionally, we will include studies with data applicable for lung cancer patients.

\section{Search strategy}

We performed an electronic article search through PubMed, Google Scholar, Medscape and Scopus databases, using combinations of the following keywords: mitomycin c, floxuridine, sirolimus, stents, lung cancer stents, dumon stents, zotarolimus, rapamycin, 5-fluorouracil, doxycycline, everolimus and pirfenidone. All types of articles (randomised controlled trials, clinical observational cohort studies, review articles, case reports) were included. Selected references from identified articles were searched for further consideration.

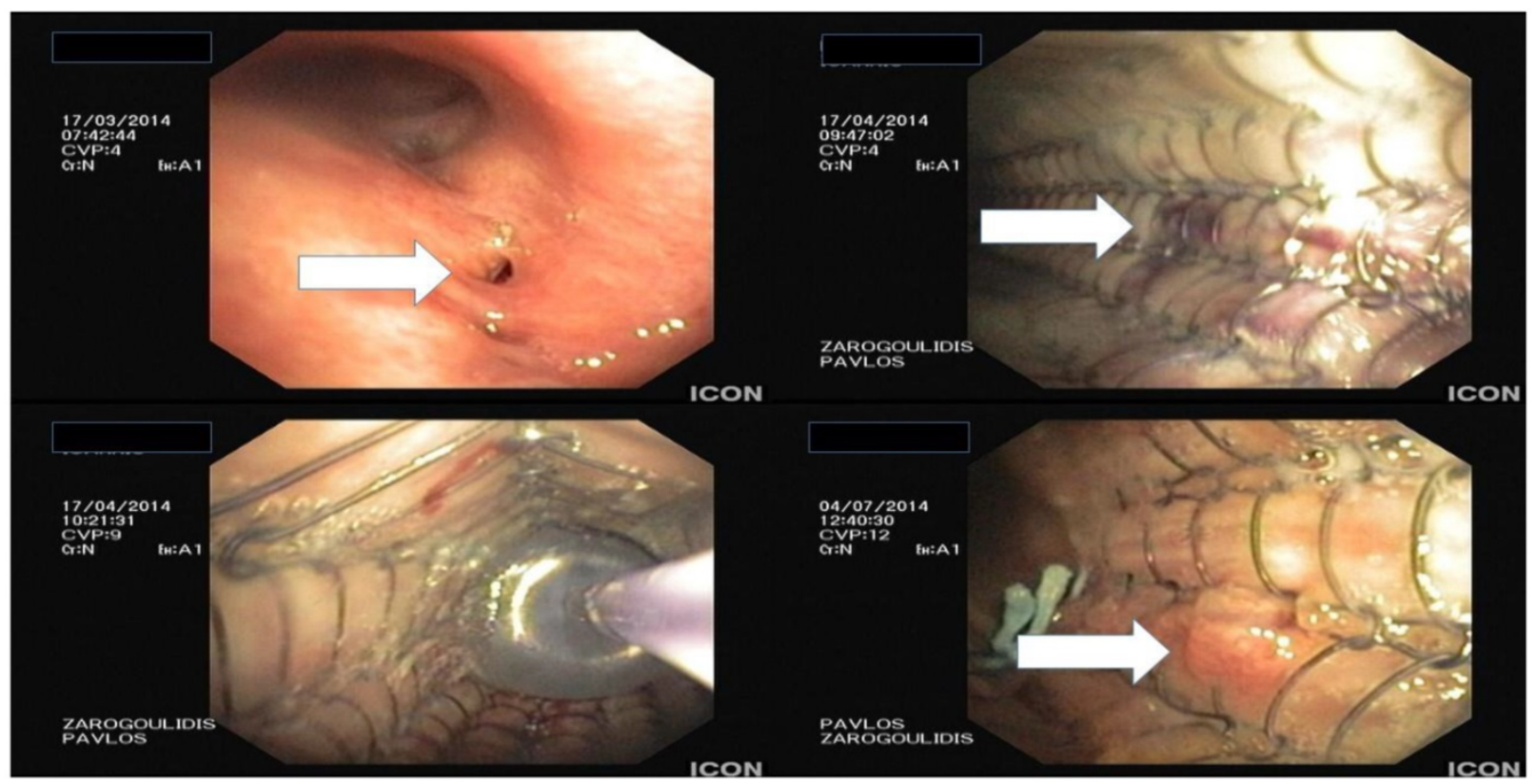

Figure 1. From top left to right bottom, hole made from excision of paratracheal tumor and covered stent placement with balloon dilation. 


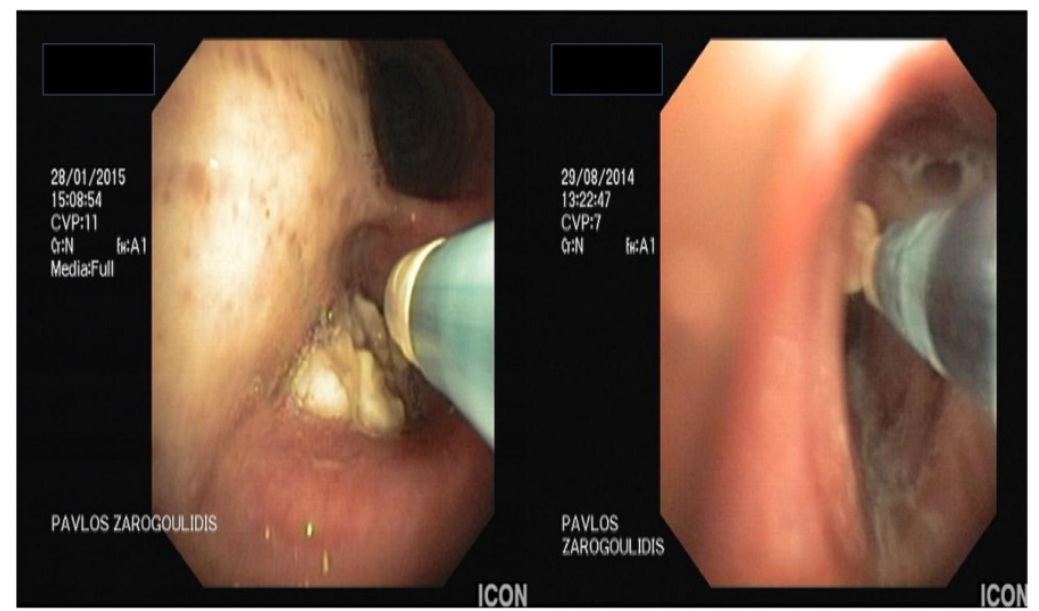

Figure 2. Argon plasma debulking.

\section{Drug Pharmacology}

\section{Cisplatin}

Cisplatin, is a well-known non-specific chemotherapy drug. It is one of the first member of a class of platinum-containing anti-cancer drugs. These days this group of drugs includes carboplatin, oxaliplatin and lipoplatin. These platinum complexes react in vivo, binding to and causing crosslinking of DNA, which finally induce apoptosis. Cisplatin is usually administered intravenously as short-term infusion in normal saline for treatment. It is used to treat (non-)small cell lung cancer, ovarian cancer, lymphomas, bladder cancer, cervical cancer, and germ cell tumors.[37] Cisplatin has been observed to be particularly effective against testicular cancer; the cure rate was improved from $10 \%$ to $85 \%$.[38]

Cisplatin is known to crosslink DNA in several different ways, interfering with cell division by mitosis. The damaged DNA elicits DNA repair mechanisms, which in turn activate apoptosis. Most notable among the changes in DNA are the 1,2-intrastrand cross-links with purine bases. These include 1,2-intrastrand $\mathrm{d}(\mathrm{GpG})$ adducts which form nearly $90 \%$ of the adducts and the less common 1,2-intrastrand $\mathrm{d}(\mathrm{ApG})$ adducts. 1,3-intrastrand $\mathrm{d}(\mathrm{GpXpG})$ adducts occur but are readily excised by the nucleotide excision repair (NER). Cisplatin has no alkyl group unable to carry out alkylating reactions. However; it is correctly classified as alkylating-like.[39, 40] Of note is the fact that different chemotherapeutic especially alkylating agents (like cyclophosphamide) play a specific role as causative for initiation / aggravation of (underlying) pulmonary hypertension in cancer patients during specific cancer treatment.[27] Such a (by chemotherapy) induced pulmonary hypertension is often classified as pulmonary veno-occlusive disease (PVOD) which resembles in many features a typical pulmonary arterial hypertension but is accompanied with a much worse prognosis in comparison to e.g. an idiopathic pulmonary arterial hypertension. Furthermore the diagnosis of induced PVOD is even more difficult when other hemodynamic comorbidities like left heart disease is already existing on chemotherapy initiation. It is worth mentioning that the establishment of the diagnosis of PVOD itself is very difficult and many times only possible post-mortal. In regards to real-life scenarios with underlying hemodynamic relevant comorbidities it is one of the most complex diagnosis in medicine in human beings alive. Therefore we believe that this diagnosis may be underscored in cancer patients and could be a part of the explanation for the still worse prognosis in many solid cancers especially under treatment despite new, very expensive targeted therapies. It has to be mentioned that any reduction of cardiac output will increase the interstitial fluid pressure intratumorally which is linked to a worse efficacy of any cancer treatment.

\section{Cisplatin resistance}

Cisplatin combination chemotherapy is the cornerstone treatment of many cancers. However; many cancer patients will eventually relapse with cisplatin-resistant disease. Mechanisms regarding the cisplatin resistance have been proposed including changes in cellular uptake and efflux of the drug, increased detoxification of the drug, inhibition of apoptosis and increased DNA repair.[41, 42] Oxaliplatin is active in highly cisplatin-resistant cancer cells in the laboratory but there is little evidence for its activity in the clinical treatment of patients with cisplatin-resistant cancer. The drug paclitaxel may be useful in the treatment of cisplatin-resistant cancer; the mechanism for this activity is yet unknown.[43] In regards to hemodynamic properties of paclitaxel it is 
of interest that this drug can influence the altitude of life limiting pulmonary hypertension positively via the Forkhead box $\mathrm{O}$ (FoxO) transcription factors which are key regulators of cellular proliferation. Using intravenous or inhaled paclitaxel will lead to pharmacological reconstitution of FoxO1 transcription factor activity in pulmonary artery smooth muscle cells (PASMCs) which serves as a potential treatment option for pulmonary hypertension.[44] This detail my be of interest when discussing chemotherapy options in cancer patients with severe pulmonary hypertension beside cancer diagnosis especially in the situation of no or minor response to first line cisplatin.

\section{Fluorouracil}

Fluorouracil is a pyrimidine analog drug which is used in the treatment of cancer. It is a suicide inhibitor and works through irreversible inhibition of thymidylate synthase. This drug is an antimetabolite. 5-Fluorouracil acts primarily as a thymidylate synthase (TS) inhibitor. Its main action is to block the synthesis of the pyrimidine thymidine which is a nucleoside required for DNA replication. Thymidylate synthase methylates deoxyuridine monophosphate (dUMP) in order to synthesize thymidine monophosphate (dTMP). The administration of 5-FU induces cell death via thymineless death.[45] Calcium folinate stabilises the 5-FU-TS complex and enhances 5-FU's cytotoxicity.[46] There is very little difference between the minimum effective dose and maximum tolerated dose of 5-FU, and it has been observed that the drug exhibits individual pharmacokinetic variability.[47-49] Therefore, an identical dose of 5-FU may result in different therapeutic response between patients.[48] It has been observed that both overdosing and underdosing are of concern with 5-FU. Moreover; the majority of colorectal cancer patients treated with 5-FU are underdosed based on today's dosing standard, body surface area (BSA).[50-53] The limitations of BSA-based dosing is an issue for many physicians as they cannot accurately titer the dosage of 5-FU for the majority of individual patients, which results in sub-optimal treatment efficacy or excessive toxicity.[51, 52]

The dihydropyrimidine dehydrogenase (DPD) enzyme is responsible for the detoxifying metabolism of fluoropyrimidines, a class of drugs that includes 5-fluorouracil, tegafur and capecitabine[54] Moreover; genetic variations within the DPD gene (DPYD) can lead to reduced or absent dihydropyrimidine dehydrogenase activity, and individuals who are heterozygous or homozygous for these variations may have partial or complete DPD deficiency. It is estimated that about $0.2 \%$ of individuals have complete dihy- dropyrimidine dehydrogenase deficiency.[54, 55] Those patients with partial or complete dihydropyrimidine dehydrogenase deficiency have increased risk of severe or even fatal drug toxicities when treated with fluoropyrimidines; such as; neurotoxicity, myelosuppression. $[55,56]$

At least two studies have found significant relationships between concentrations of 5-FU in blood plasma and both desirable or undesirable effects on patients. [52, 56] Further evaluation of the drug is based on the concentration of 5-FU in plasma that can increase desirable outcomes while minimizing negative side effects of 5-FU therapy.[52,56] Towards this direction a blood test has been created and is being used in some centers as My5-FU test.[53]

\section{Floxuridine}

Floxuridine is an antimetabolite. The drug is mostly used in the treatment of colorectal cancer. Floxuridine, an analog of 5-fluorouracil, is a fluorinated pyrimidine.

\section{Mitomycin C}

The mitomycins are a family of aziridine-containing natural products isolated from Streptomyces caespitosus or Streptomyces lavendulae. Mitomycin C (MTC, an antibiotic), finds use as a chemotherapeutic agent by virtue of its antitumour activity. It is applied intravenously to treat upper gastro-intestinal cancers (e.g. esophageal carcinoma), breast cancers and anal cancers, moreover; in bladder instillation for superficial bladder tumours. It causes delayed bone marrow toxicity and therefore it is usually administered at 6-weekly intervals. Prolonged use may result in permanent bone-marrow damage. The usual adverse effects are lung fibrosis and renal damage. Mitomycin $C$ has also been used topically rather than intravenously in several areas, like superficial cancers, particularly bladder cancers and intraperitoneal tumours. It is now well known that a single instillation of this agent within 6 hours on bladder tumor resection can prevent recurrence. Mitomycin C is a potent DNA crosslinker. A single crosslink per genome has shown to be effective in killing bacteria. This is accomplished by reductive activation followed by two N-alkylations. Both alkylations are sequence specific for a guanine nucleoside in the sequence 5'-CpG-3'.[57] Potential bis-alkylating heterocylic quinones were synthetised in order to explore their antitumoral activities by bioreductive alkylation.[58] Mitomycin is also used as a chemotherapeutic agent in glaucoma surgery.[59] In the study by Li Y. et al. [60] a novel combination of PEGylated phytosomes with mitomycin $C$ has been constructed in order to enhance the efficacy of mitomycin C. PEG complex 
has been observed in other studies that induces a "stealth" activity for several chemotherapeutic substances and in this way it produces a release effect for many cytotoxic drugs.[61, 62] In the study by Moiseyenko VM. Et al. [63] it was observed that heavily pretreated ovarian cancer patients carrying germ-line BRCA1 mutation benefited from the administration of mitomycin C. This study provides evidence that several molecular pathways of NSCLC should be investigated along with the local administration of mitomycin C (MTC). In regards to hemodynamic properties of this drug (especially in comparison to the above mentioned details for cisplatin and paclitaxel) it is of interest that MTC intravenous therapy is a potent inducer of PVOD in humans and for intraperitoneal MTC therapy in rats.[64] Amifostine prevents MTC-induced PVOD in rats and should be tested as a preventive therapy for MTC-induced PVOD in humans.

\section{Special Reference to}

\section{Pirfenidone}

Pirfenidone is an anti-fibrotic drug which is currently used in the treatment of idiopathic pulmonary fibrosis (IPF). It is known to reduce lung fibrosis through downregulation of the production of growth factors and procollagens I and II. Several studies have established its antifibrotic and anti-inflammatory properties in vitro systems and animal models of fibrosis.[65] A number of cell-based studies have shown that pirfenidone reduces fibroblast proliferation, [66-69] inhibits tumor Growth Factor- $\beta$ (TNF- $\beta$ ) stimulated collagen production[70] and reduces the production of fibrogenic mediators such as TGF- $\beta$.[68] The drug has also shown to reduce production of inflammatory mediators such as tumor growth factor-a (TNF- $\alpha$ ) and interleukin $1 \beta$ (IL-1 $\beta$ ) in both cultured cells and isolated human peripheral blood mononuclear cells.[71-74] These activities are consistent with the broader antifibrotic and anti-inflammatory activities observed in animal models of fibrosis and in vitro. $[66,69]$

\section{Everolimus}

Everolimus is known to be a derivative of sirolimus and is considered an inhibitor of mammalian target of rapamycin (mTOR). It is used as an immunosuppressant to prevent rejection of organ transplants and treatment of renal cell cancer and other tumors. Much research has also been conducted on everolimus and other mTOR inhibitors as a possible targeted therapy for use in several types of cancers. Like the others mTOR inhibitors its effect is solely on the mTORC1 protein complex and not on the mTORC2 complex. This function leads to a hy- per-activation of the kinase AKT via inhibition on the mTORC1 negative feedback loop while not inhibiting the mTORC2 positive feedback to AKT. This AKT elevation can lead to longer survival in some cell types. Based on this activity everolimus has an important effect on cell growth, cell proliferation and cell survival. It has been observed that mTORC1 action is modulated by several mitogens, growth factors and nutrients.

The two genes TSC1 and TSC2 (which are the genes involved in tuberous sclerosis disease) act as tumour suppressor genes by regulating mTORC1 activity. Therefore the loss or inactivation of one of these genes leads to the activation of mTORC1.[75]

Everolimus binds to its protein receptor FKBP12, which directly interacts with mTORC1 inhibiting its downstream signaling. As a consequence, mRNAs that codify proteins implicated in the cell cycle inhibit tumour growth.[75]

Recent trials have indicated that adding Afinitor (everolimus) to exemestane therapy against advanced breast cancer can significantly improve progression-free survival compared with exemestane therapy alone.[76, 77] However, everolimus increased mortality in cancer patients in some studies.[77-79]

Furthermore, there are two studies that show a different sensitivity to everolimus between patients depending on their genome. $[79,80]$ In a Phase II clinical trial done in patients with advanced metastasic bladder carcinoma (NCT00805129)[80] they found one person that positively responded to everolimus treatment for 26 months. A genetic sequence was performed for this patient. It was discovered that mutations in TSC1 lead to an increase in recurrence and to an increase in the response time to everolimus. Therefore, it has been determined that everolimus is more efficient in those patients that present somatic mutations in TSC1.[81]

\section{Zotarolimus}

Zotarolimus is an immunosuppressant and is considered a semi-synthetic derivative of rapamycin. It was primarily designed for use in stents with phosphorylcholine as a carrier. It was observed that coronary stents reduce early complications and improve late clinical outcomes in patients needing interventional cardiology. However, complications have been observed with stent use, such as the development of thrombosis which impedes the efficiency of coronary stents. Moreover; haemorrhagic and restenosis complications are additional problems that can be observed. Therefore drug-eluting stents have been developed. Stents are bound by a membrane consisting of polymers which releases zotarolimus slowly and its derivatives into the surrounding 
tissues. Zotarolimus is an analog made by substituting a tetrazole ring in place of the native hydroxyl group at position 42 in rapamycin. The compound is extremely lipophilic, and therefore has limited water solubility. The poor water solubility prevents rapid release into the circulation (for coronary stents) since elution of drug from the stent will be partly dissolution rate-limited. The slow rate of release and subsequent diffusion of the molecule facilitates the maintenance of therapeutic drug levels eluting from the stent. However; the surrounding tissue has to be considered too. Moreover; its lipophilic property induces crossing cell membranes to inhibit neointimal proliferation of target tissue. Zotarolimus is the most lipophilic of all drug eluting stents (DES) drugs.[82]

\section{Sirolimus}

Sirolimus (also known as rapamycin) is a chemical that was discovered as a product of bacteria Sirolimus, was originally developed as an antifungal agent. However, this use was abandoned when it was discovered to have potent immunosuppressive and antiproliferative properties. It has been shown to prolong the life of mice and might also be useful in the treatment of certain cancers. [83] Sirolimus is not a calcineurin inhibitor, but it has a similar suppressive effect on the immune system. Sirolimus inhibits interleukin-2 (IL-2) and other cytokines receptor-dependent signal transduction mechanisms, via action on mTOR, and thereby blocks the activation of $\mathrm{T}$ and $\mathrm{B}$ cells. It is known that tacrolimus and cyclosporine inhibit the secretion of IL-2, by inhibiting calcineurin. Sirolimus binds to the cytosolic protein FK-binding protein 12 (FKBP12) like tacrolimus. Unlike the tacrolimus-FKBP12 complex, which inhibits calcineurin (PP2B), the sirolimus-FKBP12 complex inhibits the mTOR (mechanistic (formerly mammalian) target of Rapamycin. Rapamycin directly binds to mTOR Complex 1 (mTORC1). mTOR has also been called FRAP (FKBP-rapamycin-associated protein), RAPT1, RAFT (rapamycin and FKBP target). Sirolimus binds to FKBP12-sirolimus complex and inhibits Tor1 and Tor2. [84-86] There have been numerous studies with sirolimus-eluting stents used for coronary disease.[87-91]. Sirolimus eluting stents have demonstrated that they can inhibit neointimal proliferation when applied next to bare metal stents.[87, 92, 93] Several groups have investigated different combinations of sirolimus and sustain release drugs in order to prolong the positive effect of the stent. [88, 89, 94, 95] Several imaging methods have been also applied in order to evaluate sirolimus stent implantation in the coronary vessels. [91, 96, 97]In the study by Habib et. al. [98] it was observed that metformin impairs vascular endothelial recovery after stent place- ment in the setting of locally eluted mammalian target of rapamycin inhibitors. Metformin could therefore be administered as an adjuvant treatment for these patients or added in the eluting solution. The administration of granulocyte colony-stimulating factor has been observed to attenuate endothelial dysfunction after sirolimus eluting stent implantation.[99] In the study by Erdim et. al. [100] and Tarantini et. al. [101] there were a difference observed between paclitaxel eluting stents and sirolimus eluting stents. The same was true when sirolimus and paclitaxel eluting stents were compared to bare metal stents.[102]

\section{Paclitaxel}

Paclitaxel is used to treat a number of cancers such as; ovarian cancer, breast cancer, lung cancer and pancreatic cancer. Paclitaxel and docetaxel represent the taxane family of drugs. Paclitaxel's mechanism of action involves interference with the normal breakdown of microtubules during cell division. Its common side effects include: muscle and joint pains, hair loss, and diarrhea. Anaemia and infections can occur and can be potentially serious. It should not be used during pregnancy as it often results in problems in the infant. Paclitaxel is used as an antiproliferative agent for the prevention of restenosis (recurrent narrowing) of coronary and peripheral stents; locally delivered to the artery wall. It has been observed that paclitaxel coating limits the growth of neointima (scar tissue) within stents.[103] It is known that paclitaxel targets tubulin. Paclitaxel-treated cells have defects in mitotic spindle assembly, chromosome segregation, and cell division. Paclitaxel stabilizes the microtubule polymer and protects it from disassembly. Consequently chromosomes are unable to achieve a metaphase spindle configuration. This function blocks progression of mitosis, and prolonged activation of the mitotic checkpoint triggers apoptosis or reversion to the G-phase of the cell cycle without cell division. It has been observed that the ability of paclitaxel to inhibit spindle function is generally attributed to its suppression of microtubule dynamics. Moreover; in vitro studies it has been observed that at higher therapeutic concentrations, paclitaxel appears to suppress microtubule detachment from centrosomes. This process occurs during mitosis. Paclitaxel binds to beta-tubulin subunits of microtubules.[104-108] Paclitaxel eluting stents have been used for airway bypass [109] and for coronary vessel implantation.[100-102, 110-114] Paclitaxel solution has been also conjugated with a carrier in order to produce a sustain drug release effect.[115]

\section{Doxycline}

Doxycycline is a broad-spectrum antibiotic of the 
tetracycline class that is useful for the treatment of many infections. Doxycycline-metal ion complexes are unstable at acid $\mathrm{pH}$, therefore more doxycycline enters the duodenum for absorption while other earlier tetracycline compounds are released in the upper gastrointestinal tract. Moreover; it was mentioned that food has less effect on absorption than on absorption of earlier drugs with doxycycline serum concentrations being reduced by about $20 \%$ by test meals compared with $50 \%$ for tetracycline.[116] Expired tetracyclines or tetracyclines allowed to stand at a $\mathrm{pH}$ less than 2 are reported to be nephrotoxic due to the formation of a degradation product, such as the hydro-4-epitetracycline which induces the Fanconi syndrome. It is known for doxycycline that the absence of a hydroxyl group in C-6 prevents the formation of this nephrotoxic compound. Tetracyclines and doxycycline itself have to be taken with precaution by patients with kidney injury, as they can worsen azotemia due to catabolic effects.[117] In the study by Huvenne W. et. al. [36] it was observed that doxycycline-releasing stents improved postoperative healing after functional endoscopic sinus surgery.

\section{Sirolimus vs. Everolimus}

In the study by Gao R. et. al. [94] novel abluminal groove-filled biodegradable polymer sirolimus eluting stent was investigated versus a durable polymer everolimus-eluting stent: None of the two stents presented positive results after 12 months follow up and none was observed to be superior. Regarding the novel abluminal groove-filled biodegradable polymer sirolimus eluting stent the authors stated that the stent was not inferior to the everolimus stent. The stents were found to be effective mainly for the first nine months. In the study by Smits P. C. et. al. [118] abluminal biodegradable polymer biolimus-eluting stents were tested versus durable polymer everolimus stents: This time the biolimus stents were found to be as effective as the everolimus stents. In the study by Harjai K. J. et. al. [110] it was observed that everolimus eluting stents were more efficient when compared to sirolimus and paclitaxel eluting stents at least for 3 months of follow up. Again in the study by Park K. W. et. al. [119] Kitabata H. et. al. [120], Moreno R. et. al. [121], Kozuma K. et. al. [122] and Ko Y-G. et. al. [97] everolimus eluting stents were found to be superior when compared to sirolimus eluting stents.

\section{Zotarolimus vs. Everolimus}

In the study by Tandjung K. et. al. [123] no difference was observed between the zotarolimus and everolimus stents in terms of safety and efficiency. However; in the study by Kim S. et. al. [124] although zotarolimus had rapid neointimal healing at 3 months, the zotarolimus stents had a slightly better vascular healing profile at long term 12 months. In the study by Park K. W. et. al. [125] both zotarolimus and everolimus stents showed the same safety and efficiency profile after 1 year follow-up.

\section{Zotarolimus vs. Paclitaxel}

In the study by Xu B. et. al. [126] It was observed that zotarolimus stents were more efficient when compared to paclitaxel eluting stents within 12 months of follow up.

\section{Sirolimus vs. Zotarolimus}

In the study by Van den Branden B. et. al. [127] sirolimus eluting stents were found to have higher efficiency than zotarolimus stents.

\section{Stent Studies for the respiratory tract}

\section{Cisplatin}

In the study by Chao YK et al. [35] biodegradable stents made of polycaprolactone were fabricated by a laboratory-made, microinjection molding machine. Initially, in vitro mechanical strength of the stents was compared with the strength of Ultraflex SEMSs. Polylactide-polyglycolide copolymer and cisplatin were coated onto the surfaces of the stents. Elution method and high-performance liquid chromatography (HPLC) analysis were used to examine the in vitro cisplatin release characteristics. In vivo, the stents were surgically implanted into the cervical trachea of white rabbits. Bronchoscopic examination was performed weekly and Cisplatin concentrations in trachea, lung, and blood were analyzed by HPLC. Histologic examination was also performed. The biodegradable stent exhibited mechanical strength comparable to the strength of Ultraflex SEMSs and provided a steady release of cisplatin for 4 weeks in vitro. The in vivo study showed sustained cisplatin levels in rabbit trachea for 5 weeks with a minimum drug level in blood. Histologic examination showed an intact ciliated epithelium and marked leukocyte infiltration in the submucosa of the stented area.

\section{Mitomycin C}

In the study by Choomg C. K. et al. [128] mitomycin C (MTC) was administered locally after stent placement for airway bypass and blocked granuloma tissue formation for up to a week. In the study by Coppit G. et. al. [129] MTC failed to affect the acute inflammatory response, perhaps secondary to the robust inflammatory reaction created by combining a single-stage laryngotracheal reconstruction (SSLTR) with the local circumferential trauma induced by the Palmaz stent. This may have reduced the beneficial effects of the MTC in this study. However; incorpora- 
tion of the auricular cartilage graft the stent was improved, contributing again to improved airway stability. The mechanism of this action is not yet understood, as MTC is considered a potent fibroblast inhibitor and not a promoter of neochondrogenesis. It is possible that this is an effect of MTC not previously described. In the study by Sztano B. et. al. [130] mitomycin $\mathrm{C}$ prolonged fibrotic tissue formation for almost 6 weeks in a young boy. On the other hand in the study by Uzomefuna V. et. al. [131] again it did not present a positive antiproliferative effect, however; the authors provide data where the effect might be associated with the patients' age. In the study by Carter J. M. et. al. [132] the positive application of MTC was observed with fewer days of hospitalization. In another study by Kim H. et. al. [133] investigating again the effect of MTC application in congenital choanal atresia as in the study by Carter J. M. et. al. [132] no positive effect was observed in this group. In the study by Cardoso P.F.G. et.al. [109] paclitaxel eluting stents were used for airway bypass. Initial results indicated reduction of hyperinflation and improved pulmonary function and dyspnea. In the study by Choong C.K. et. al. [134] in an animal model prolongation of patency was observed. However; in the study by Shah P.L. et. al. [135] no benefit was observed from these stents for homogenous emphysema. Although a previous study by the same group implicated that these patients might benefit from these stents.[136] In the study by Zhu G. H. et. al. [137] bioabsorbable tubular stents eluting MTC (tracheal) were created and they were found to be superior to silicone stents. This study is very important because it provides data regarding the importance of the stent design in mucus trapping. The authors propose a stent design along with a drug eluting carrier, however; further investigation is needed for the stent design.

\section{Doxycycline}

In the study by Huvenne W. et. al. [36] doxycycline drug eluting stents were designed and applied for sinus surgery. It was observed that matrix metalloproteinase-(MMP-9) levels were lower along with bacterial colonization and additionally short time healing was observed.

\section{Carriers designed for coronary, airway and gastrointestinal stents}

In the study by Bang S. et. al. [138] paclitaxel-eluting membranes were designed in order to release paclitaxel: Positive results have been observed for more than 15 days after implantation. In the study by Qiu $H$. et. al. [88] sirolimus bioabsorable poly-L-lactic acid stents were designed and were ef- fective up to 28 days. In the study by Deng J. et. al. [89] a nanoporous CREG-sirolimus eluting stent was designed with positive effects between 2-4 weeks. In the study by Christiansen E. H. et. al. [139] a biolimus-eluting biodegradable polymer-coated stent was compared to durable polymer-coated sirolimus-eluting stent, however; after 1 year the results did not indicate a superiority of these novel stents. In the study by Gao R. et. al. [94] novel abluminal groove-filled biodegradable polymer sirolimus eluting stent was investigated versus a durable polymer everolimus-eluting stent: None of the two stents presented positive results after 12 months follow up and none was observed to be superior from one another. In the study by Huvenne W. et. al. [36] a doxycycline eluting stent was created from copolymer blocks. It was observed that matrix metalloproteinase-(MMP-9) levels were lower along with bacterial colonization and additionally short time healing was observed. In the study by Chao Y. et. al. [35] polylactide-polyglycolide copolymer-cisplatin stents were designed and a sustainable release was observed for up to 5 weeks. In the study by Lemos P. et. al. [140] using polymer-free phospholipid encapsulated sirolimus nanocarriers stents the drug transfer was feasible to all layers of the vessel wall, achieving high tissue concentration that persisted days after the application. In the study by Seo J-B. et. al. [113] two different types of paclitaxel eluting stents were investigated: The polymer polysulfone (Coroflex) and polymer "Translute" (Taxus). The Taxus stent was observed to be superior to the Coroflex within a 9 month follow up.

\section{Discussion}

The inherent growth inhibitory properties of many anti-cancer agents make these drugs ideal candidates for the prevention of restenosis. However, these same properties are often associated with local cytotoxicity such as; fistulas. Therefore a multimodality approach is necessary either with debulking and then stent placement or radiotherapy when appropriate. Performance status, comorbidities, disease extend and anatomical malformations of the patient should be considered.

Preparation is necessary in many cases as airway malformation is observed and therefore 3 dimensional investigation has been proposed.[141] In the study by Ratnovsky A. et. al. [28] the stress of different materials were investigated and the authors proposed a patient-specific trachea model evaluation before stenting the patient. The method of stent application/stress, different material and different tissue (benign/malignant) could probably be assessed one day for each patient before application in order to avoid 
adverse effects. Since MTC is an antitumour drug that is used in both benign and malignant tissue formation after stent placement, we suggest that other cytotoxic agents with or without carrier that modulate the release of the drug locally should be investigated.[57] Regarding pirfenidone, we cannot propose further studies when we have tissue formation around the edge of a stent if the underlying disease is cancer, however; it would be interesting to design pirfenidone eluting stents for benign obstructions. In the study by Barone-Rochette G. et. al. [142] data are presented where current technology of drug eluting stents is cost effective and therefore novel stents should be encouraged. An issue to be investigated is whether we should provide the patients with an adjuvant therapy when implanting an airway stent. There is the case of the immunosuppressant rapamycin which was the basis for the development of zotarolimus by Johnson and Johnson. Rapamycin was originally approved for the prevention of renal transplant rejection in 1999. There is evidence for coronary stents that when metformin is administered impairment of vascular endothelial recovery is observed. More studies should be performed towards this direction. Another issue is the adverse effects of the drugs that are conjugated with the stent. There is a case reported where a zotarolimus eluting stent induced hypersensitivity pneumonitis.[143] In the study by Iwata Y. et. al. [99] granulocyte colony-stimulating factor was administered and it was observed that endothelial dysfunction was attenuated after sirolimus eluting stents implantation. Again in the study by Rhew S. H. et. al. [144] repeated catastrophic multi-vessel coronary spam was observed after zotarolimus-eluting stent. In the study by Zhu G. H. et. al. [137] bioabsorbable tubular tracheal stents eluting MTC were created and found to be superior to silicone stents. This study is very important because it provides data regarding the importance of the stent design in mucus trapping. The authors propose a stent design along with a drug eluting carrier, however; further investigation is needed for the stent design. 5- fluorouracil (5-FU) nitinol stents have been used for the gastrointestinal tract, and could be investigated for the respiratory tract.[145] There are currently novel methods for evaluating the concentration of paclitaxel and 5-FU simultaneously [146], moreover; novel ampiphilic copolymers have been designed to control the drug release such as; 5-FU.[146-148] (Figure 3, Tables 1-2)

In our mini review we investigate the current knowledge from the coronary drug eluting stents and we present also a comparison between the different materials. We are trying to create a bridge between this knowledge and the data that we obtained from eluting airway stent techniques. There has not been much effort towards stents for lung cancer patients. The main reason is that patients usually have a low performance status when stents are applied usually as palliative treatment. Moreover; interventional pulmonology has many tools for rapid local control. However; a long term local therapy through airway stents for these patients is welcomed. Going through the literature we believe that an ideal airway stent should (1) possess sufficient strength to perform its mechanical function, (2) be biocompatible so that the material breakdown process will not cause any tissue irritation, (3) be biodegradable (no need for removal after serving its purpose), and/or (4) provide effective pharmaceuticals for a sustained period of time. Before stent placement we propose investigation of the airways with computertomography scans and bronchoscopy in order to choose the best stent design and make the appropriate intervention. Finally, the type of lung cancer should direct us to choose the appropriate drug in order to invent drug eluting stents. Agents effective against specific types of lung cancers have been found, such as permetrexed for adenocarcinoma or TKIs for EGFR or ALK positive patients.

Table 1. Stent studies (In the result section the referenced time indicates the time where the first positive results were observed.)

\begin{tabular}{llll}
\hline Author & Subject & Drug & Result \\
\hline Chao Y.K. et. Al. & animals & Cisplatin with carrier & 5 week with apoptosis \\
Choong C.K. et al. & animals & Mitomycin C & 1 week \\
Coppit G. et. al. & animals & Mitomycin C & No effect \\
Sztano B.et. al. & human & Mitomycin C & 6 weeks \\
Uzomefuna V. et. al. & human & Mitomycin C & No effect \\
Carter J. M. et. al. & human & Mitomycin C & Less hospitilisation days \\
Kim H. et. al. & human & Mitomycin C & No effect \\
Cardoso F.G.P. et. al. & human & Paclitaxel & Positive effect (emphysema application) \\
Choong C. K. et. al. & animal & Paclitaxel & Prolongation of patency \\
Shah P.L.et. al. & human & Paclitaxel & No benefit, however; safe \\
Huvenne W. et. al. & human & Doxycycline & Shorter healing time, less bacterial colonization, lower MMP-9 levels \\
\hline
\end{tabular}


Table 2. Carriers designed for coronary and airway stents.

\section{-Paclitaxel eluting stents}

-Sirolimus bioabsorable poly-L-lactic acid

-Nanoporous CREGES (Sirolimus)

-Biolimus-eluting biodegradable polymer-coated stent

-Novel abluminal groove-filled biodegradable polymer sirolimus eluting stent

-Doxycycline eluting stent was created from copolymer blocks

-Polylactide-polyglycolide copolymer-cisplatin

-Polymer-free phospholipid encapsulated sirolimus nanocarriers

-Bioabsorbable tubular stents

-Amphiphilic poly( $\varepsilon$-caprolactone)-poly(ethylene glycol)-poly( $\varepsilon$-caprolactone) (PCL-PEG-PCL) copolymers

- trilayered Poly( $\varepsilon$-caprolactone) (PCL)-based film with a coating layer (CL), a drug-storing layer (DSL)

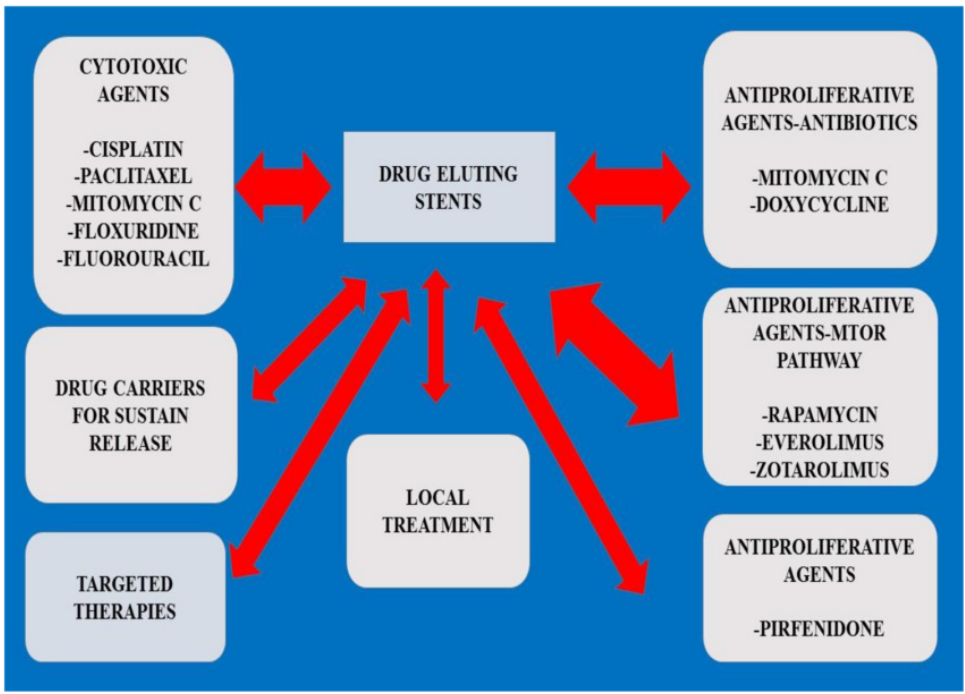

Figure 3. Drug eluting stents algorithm.

\section{Conflict of Interest}

None to declare.

\section{References}

1. Rosso T, Bertuccio P, La Vecchia C, Negri E, Malvezzi M. Cancer mortality trend analysis in Italy, 1980-2010, and predictions for 2015. Tumori. 2015; 0: 0 . doi: $10.5301 /$ tj. 5000352

2. Chin J, Syrek Jensen $T$, Ashby L, Hermansen J, Hutter JD, Conway PH. Screening for lung cancer with low-dose CT--translating science into Medicare coverage policy. The New England journal of medicine. 2015; 372: 2083-5. doi:10.1056/NEJMp1502598.

3. Omura $Y, L u$ D, O'Young B, Jones $M$, Nihrane A, Duvvi $H$, et al. New non-invasive safe, quick, economical method of detecting various cancers was found using QRS complex or rising part of T-wave of recorded ECGs. Cancers can be screened along with their biochemical parameters \& therapeutic effects of any cancer treatments can be evaluated using recorded ECGs of the same individual. Acupuncture \& electro-therapeutics research. 2015; 40: 1-15.

4. Gao L, Xie E, Yu T, Chen D, Zhang L, Zhang B, et al. Methylated APC and RASSF1A in multiple specimens contribute to the differential diagnosis of patients with undetermined solitary pulmonary nodules. Journal of thoracic disease. 2015; 7: 422-32. doi:10.3978/j.issn.2072-1439.2015.01.24.

5. Zaric B, Stojsic V, Tepavac A, Sarcev $\mathrm{T}$, Zarogoulidis $\mathrm{P}$, Darwiche $\mathrm{K}$, et al. Adjuvant chemotherapy and radiotherapy in the treatment of non-small cell lung cancer (NSCLC). Journal of thoracic disease. 2013; 5 Suppl 4: S371-7. doi:10.3978/j.issn.2072-1439.2013.05.16.

6. Domvri K, Zarogoulidis P, Darwiche K, Browning RF, Li Q, Turner JF, et al. Molecular Targeted Drugs and Biomarkers in NSCLC, the Evolving Role of Individualized Therapy. Journal of Cancer. 2013; 4: 736-54. doi:10.7150/jca.7734.

7. Lampaki S, Lazaridis G, Zarogoulidis K, Kioumis I, Papaiwannou A, Tsirgogianni $\mathrm{K}$, et al. Defining the role of tyrosine kinase inhibitors in early stage non-small cell lung cancer. Journal of Cancer. 2015; 6: 568-74. doi:10.7150/jca.11893.

8. Zarogoulidis K, Zarogoulidis P, Darwiche K, Boutsikou E, Machairiotis N, Tsakiridis $\mathrm{K}$, et al. Treatment of non-small cell lung cancer (NSCLC). Journal of thoracic disease. 2013; 5 Suppl 4: S389-96. doi:10.3978/j.issn.2072-1439.2013.07.10.

9. Domvri K, Bougiouklis D, Zarogoulidis P, Porpodis K, Xristoforidis M, Liaka A, et al. Could Somatostatin Enhance the Outcomes of Chemotherapeutic Treatment in SCLC? Journal of Cancer. 2015; 6: 360-6. doi:10.7150/jca.11308.

10. Zarogoulidis K, Eleftheriadou E, Kontakiotis T, Gerasimou G, Zarogoulidis P, Sapardanis I, et al. Long acting somatostatin analogues in combination to antineoplastic agents in the treatment of small cell lung cancer patients. Lung cancer. 2012; 76: 84-8. doi:10.1016/j.lungcan.2011.09.014.

11. Mairinger FD, Walter RF, Theegarten D, Hager T, Vollbrecht C, Christoph DC et al. Gene Expression Analysis of the 26S Proteasome Subunit PSMB4 Reveals Significant Upregulation, Different Expression and Association with Proliferation in Human Pulmonary Neuroendocrine Tumours. Journal of Cancer. 2014; 5: 646-54. doi:10.7150/jca.9955.

12. Zarogoulidis K, Ziogas E, Boutsikou E, Zarogoulidis P, Darwiche K, Kontakiotis $\mathrm{T}$, et al. Immunomodifiers in combination with conventional chemotherapy in small cell lung cancer: a phase II, randomized study. Drug design, development and therapy. 2013; 7: 611-7. doi:10.2147/DDDT.S43184.

13. Zarogoulidis K, Ziogas E, Papagiannis A, Charitopoulos K, Dimitriadis K, Economides D, et al. Interferon alpha-2a and combined chemotherapy as first line treatment in SCLC patients: a randomized trial. Lung cancer. 1996; 15: 197-205.

14. Zarogoulidis K, Latsios D, Porpodis K, Zarogoulidis P, Darwiche K, Antoniou $\mathrm{N}$, et al. New dilemmas in small-cell lung cancer TNM clinical staging. OncoTargets and therapy. 2013; 6: 539-47. doi:10.2147/OTT.S44201.

15. Zarogoulidou V, Panagopoulou E, Papakosta D, Petridis D, Porpodis K, Zarogoulidis $\mathrm{K}$, et al. Estimating the direct and indirect costs of lung cancer: a prospective analysis in a Greek University Pulmonary Department. Journal of thoracic disease. 2015; 7: S12-9. doi:10.3978/j.issn.2072-1439.2015.01.57.

16. Lithoxopoulou $\mathrm{H}$, Zarogoulidis $\mathrm{K}$, Bostantzopoulou S, Eleftheriadou $\mathrm{E}$, Zarogoulidis $\mathrm{P}$, Huang $\mathrm{H}$, et al. Monitoring changes in quality of life in patients 
with lung cancer by using specialised questionnaires: implications for clinical practice. Supportive care in cancer : official journal of the Multinational Association of Supportive Care in Cancer. 2014; 22: 2177-83. doi:10.1007/s00520-014-2205-4.

17. Freitag L, Darwiche K. Endoscopic treatment of tracheal stenosis. Thoracic surgery clinics. 2014; 24: 27-40. doi:10.1016/j.thorsurg.2013.10.003.

18. Zarogoulidis P, Darwiche K, Tsakiridis K, Teschler H, Yarmus L, Zarogoulidis $\mathrm{K}$, et al. Learning from the Cardiologists and Developing Eluting Stents Targeting the Mtor Pathway for Pulmonary Application; A Future Concept for Tracheal Stenosis. Journal of molecular and genetic medicine : an international journal of biomedical research. 2013; 7: 65. doi:10.4172/1747-0862.1000065.

19. Hohenforst-Schmidt W, Linsmeier B, Zarogoulidis P, Freitag L, Darwiche K, Browning $R$, et al. Transtracheal single-point stent fixation in posttracheotomy tracheomalacia under cone-beam computer tomography guidance by transmural suturing with the Berci needle - a perspective on a new tool to avoid stent migration of Dumon stents. Therapeutics and clinical risk management. 2015; 11: 837-50. doi:10.2147/TCRM.S83230.

20. Bolliger CT, Sutedja TG, Strausz J, Freitag L. Therapeutic bronchoscopy with immediate effect: laser, electrocautery, argon plasma coagulation and stents. The European respiratory journal. 2006; 27: 1258-71. doi:10.1183/09031936.06.00013906.

21. Freitag L. Interventional endoscopic treatment. Lung cancer. 2004; 45 Suppl 2: S235-8. doi:10.1016/j.lungcan.2004.07.970.

22. Freitag L, Ernst A, Thomas M, Prenzel R, Wahlers B, Macha HN. Sequential photodynamic therapy (PDT) and high dose brachytherapy for endobronchial tumour control in patients with limited bronchogenic carcinoma. Thorax. 2004; 59: 790-3. doi:10.1136/thx.2003.013599.

23. Freitag L. PDT in early central lung cancer. Thorax. 2007; 62: 374-5. doi:10.1136/thx.2006.067892.

24. Freitag L, Ernst A, Unger M, Kovitz K, Marquette CH. A proposed classification system of central airway stenosis. The European respiratory journal. 2007; 30: 7-12. doi:10.1183/09031936.00132804.

25. Stamatis G, Freitag L. [Tracheoesophageal fistula]. Der Chirurg; Zeitschrift fur alle Gebiete der operativen Medizen. 2011; 82: 148-53. doi:10.1007/s00104-010-1977-4

26. Freitag L, Tekolf E, Steveling H, Donovan TJ, Stamatis G. Management of malignant esophagotracheal fistulas with airway stenting and double stenting. Chest. 1996; 110: 1155-60.

27. Ranchoux B, Gunther S, Quarck R, Chaumais MC, Dorfmuller P, Antigny F, et al. Chemotherapy-induced pulmonary hypertension: role of alkylating agents. The American journal of pathology. 2015; 185: 356-71. doi:10.1016/j.ajpath.2014.10.021.

28. Ratnovsky A, Regev N, Wald S, Kramer M, Naftali S. Mechanical properties of different airway stents. Medical engineering \& physics. 2015; 37: 408-15. doi:10.1016/j.medengphy.2015.02.008.

29. Crino L, Metro G. Therapeutic options targeting angiogenesis in nonsmall cell lung cancer. European respiratory review : an official journal of the European Respiratory Society. 2014; 23: 79-91. doi:10.1183/09059180.00008913.

30. Grundmann S, Hoefer I, Bode C. [Cytokine-eluting stents as new drug-delivery devices for angiogenic therapy]. Hamostaseologie. 2008; 28: 195-202.

31. Malgras B, Brulle L, Lo Dico R, El Marjou F, Robine S, Therwath A, et al. Insertion of a Stent in Obstructive Colon Cancer Can Induce a Metastatic Process in an Experimental Murine Model. Annals of surgical oncology. 2015. doi:10.1245/s10434-015-4588-y.

32. Mizokami D, Araki K, Tanaka N, Suzuki H, Tomifuji M, Yamashita T, et al. Tacrolimus prevents laryngotracheal stenosis in an acute-injury rat model. The Laryngoscope. 2015; 125: E210-5. doi:10.1002/lary.25178.

33. Kong Y, Zhang J, Wang T, Qiu X, Wang Y. Preparation and characterization of paclitaxel-loaded poly lactic acid-co-glycolic acid coating tracheal stent. Chinese medical journal. 2014; 127: 2236-40.

34. Chen N, Zhang J, Xu M, Wang T, Wang YL, Pei YH. [The influence of mitomycin $C$ and paclitaxel on the proliferation and apoptosis of human pulmonary fibroblast]. Zhonghua jie he he hu xi za zhi = Zhonghua jiehe he huxi zazhi $=$ Chinese journal of tuberculosis and respiratory diseases. 2013; 36: 655-60.

35. Chao YK, Liu KS, Wang YC, Huang YL, Liu SJ. Biodegradable cisplatin-eluting tracheal stent for malignant airway obstruction: in vivo and in vitro studies. Chest. 2013; 144: 193-9. doi:10.1378/chest.12-2282.

36. Huvenne W, Zhang N, Tijsma E, Hissong B, Huurdeman J, Holtappels G, et al. Pilot study using doxycycline-releasing stents to ameliorate postoperative healing quality after sinus surgery. Wound repair and regeneration : official publication of the Wound Healing Society [and] the European Tissue Repair Society. 2008; 16: 757-67. doi:10.1111/j.1524-475X.2008.00429.x.

37. Mehmood RK. Review of Cisplatin and oxaliplatin in current immunogenic and monoclonal antibody treatments. Oncology reviews. 2014; 8: 256. doi:10.4081/oncol.2014.256

38. Einhorn LH. Treatment of testicular cancer: a new and improved model. Journal of clinical oncology : official journal of the American Society of Clinical Oncology. 1990; 8: 1777-81.

39. Wang D, Lippard SJ. Cellular processing of platinum anticancer drugs. Nature reviews Drug discovery. 2005; 4: 307-20. doi:10.1038/nrd1691.

40. Pruefer FG, Lizarraga F, Maldonado V, Melendez-Zajgla J. Participation of Omi Htra2 serine-protease activity in the apoptosis induced by cisplatin on
SW480 colon cancer cells. Journal of chemotherapy. 2008; 20: 348-54. doi:10.1179/joc.2008.20.3.348.

41. Stordal B, Davey M. Understanding cisplatin resistance using cellular models. IUBMB life. 2007; 59: 696-9. doi:10.1080/15216540701636287.

42. Stordal BK, Davey MW, Davey RA. Oxaliplatin induces drug resistance more rapidly than cisplatin in $\mathrm{H} 69$ small cell lung cancer cells. Cancer chemotherapy and pharmacology. 2006; 58: 256-65. doi:10.1007/s00280-005-0148-7.

43. Stordal B, Hamon M, McEneaney V, Roche S, Gillet JP, O'Leary JJ, et al. Resistance to paclitaxel in a cisplatin-resistant ovarian cancer cell line is mediated by P-glycoprotein. PloS one. 2012; 7: e40717. doi:10.1371/journal.pone.0040717.

44. Savai R, Al-Tamari HM, Sedding D, Kojonazarov B, Muecke C, Teske R, et al. Pro-proliferative and inflammatory signaling converge on FoxO1 transcription factor in pulmonary hypertension. Nature medicine. 2014; 20: 1289-300. doi:10.1038/nm.3695.

45. Longley DB, Harkin DP, Johnston PG. 5-fluorouracil: mechanisms of action and clinical strategies. Nature reviews Cancer. 2003; 3: 330-8. doi:10.1038/nrc1074.

46. Alvarez P, Marchal JA, Boulaiz H, Carrillo E, Velez C, Rodriguez-Serrano F, et al. 5-Fluorouracil derivatives: a patent review. Expert opinion on therapeutic patents. 2012; 22: 107-23. doi:10.1517/13543776.2012.661413.

47. Felici A, Verweij J, Sparreboom A. Dosing strategies for anticancer drugs: the good, the bad and body-surface area. European journal of cancer. 2002; 38: 1677-84

48. Gamelin E, Boisdron-Celle M. Dose monitoring of 5-fluorouracil in patients with colorectal or head and neck cancer--status of the art. Critical reviews in oncology/hematology. 1999; 30: 71-9.

49. Baker SD, Verweij J, Rowinsky EK, Donehower RC, Schellens JH, Grochow LB, et al. Role of body surface area in dosing of investigational anticancer agents in adults, 1991-2001. Journal of the National Cancer Institute. 2002; 94: 1883-8.

50. Goldberg RM, Rothenberg ML, Van Cutsem E, Benson AB, 3rd, Blanke CD, Diasio RB, et al. The continuum of care: a paradigm for the management of metastatic colorectal cancer. The oncologist. 2007; 12: 38-50. doi:10.1634/theoncologist.12-1-38.

51. Saam J, Critchfield GC, Hamilton SA, Roa BB, Wenstrup RJ, Kaldate RR. Body surface area-based dosing of 5-fluoruracil results in extensive interindividual variability in 5-fluorouracil exposure in colorectal cancer patients on FOLFOX regimens. Clinical colorectal cancer. 2011; 10: 203-6. doi:10.1016/j.clcc.2011.03.015.

52. Capitain O, Asevoaia A, Boisdron-Celle M, Poirier AL, Morel A, Gamelin E. Individual fluorouracil dose adjustment in FOLFOX based on pharmacokinetic follow-up compared with conventional body-area-surface dosing: a phase II, proof-of-concept study. Clinical colorectal cancer. 2012; 11: 263-7. doi:10.1016/j.clcc.2012.05.004

53. Beumer JH, Boisdron-Celle M, Clarke W, Courtney JB, Egorin MJ, Gamelin E, et al. Multicenter evaluation of a novel nanoparticle immunoassay for 5 -fluorouracil on the Olympus AU400 analyzer. Therapeutic drug monitoring. 2009; 31: 688-94. doi:10.1519/JSC.0b013e3181b866d0.

54. Caudle KE, Thorn CF, Klein TE, Swen JJ, McLeod HL, Diasio RB, et al. Clinical Pharmacogenetics Implementation Consortium guidelines for dihydropyrimidine dehydrogenase genotype and fluoropyrimidine dosing. Clinical pharmacology and therapeutics. 2013; 94: 640-5. doi:10.1038/clpt.2013.172.

55. Amstutz U, Froehlich TK, Largiader CR. Dihydropyrimidine dehydrogenase gene as a major predictor of severe 5-fluorouracil toxicity. Pharmacogenomics. 2011; 12: 1321-36. doi:10.2217/pgs.11.72.

56. Gamelin E, Delva R, Jacob J, Merrouche Y, Raoul JL, Pezet D, et al. Individual fluorouracil dose adjustment based on pharmacokinetic follow-up compared with conventional dosage: results of a multicenter randomized trial of patients with metastatic colorectal cancer. Journal of clinical oncology : official journal of the American Society of Clinical Oncology. 2008; 26: 2099-105. doi:10.1200/JCO.2007.13.3934.

57. Tomasz M. Mitomycin C: small, fast and deadly (but very selective). Chemistry \& biology. 1995; 2: 575-9.

58. Zheng Z, Touve M, Barnes J, Reich N, Zhang L. Synthesis-enabled probing of mitosene structural space leads to improved IC(5)(0) over mitomycin C. Angewandte Chemie. 2014; 53: 9302-5. doi:10.1002/anie.201402268.

59. Na JH, Sung KR, Shin JA, Moon JI. Antifibrotic effects of pirfenidone on Tenon's fibroblasts in glaucomatous eyes: comparison with mitomycin $\mathrm{C}$ and 5-fluorouracil. Graefe's archive for clinical and experimental ophthalmology = Albrecht von Graefes Archiv fur klinische und experimentelle Ophthalmologie. 2015. doi:10.1007/s00417-015-3068-1.

60. Li Y, Wu H, Jia M, Cui F, Lin J, Yang X, et al. Therapeutic effect of folate-targeted and PEGylated phytosomes loaded with a mitomycin C-soybean phosphatidyhlcholine complex. Molecular pharmaceutics. 2014; 11: 3017-26. doi:10.1021/mp5001873.

61. Zarogoulidis P, Chatzaki E, Porpodis K, Domvri K, Hohenforst-Schmidt W, Goldberg EP, et al. Inhaled chemotherapy in lung cancer: future concept of nanomedicine. International journal of nanomedicine. 2012; 7: 1551-72. doi:10.2147/IJN.S29997.

62. Zarogoulidis P, Giraleli C, Karamanos NK. Inhaled chemotherapy in lung cancer: safety concerns of nanocomplexes delivered. Therapeutic delivery. 2012; 3: 1021-3.

63. Moiseyenko VM, Chubenko VA, Moiseyenko FV, Zhabina AS, Gorodnova TV, Komarov YI, et al. Evidence for clinical efficacy of mitomycin $C$ in heavily 
pretreated ovarian cancer patients carrying germ-line BRCA1 mutation. Medical oncology. 2014; 31: 199. doi:10.1007/s12032-014-0199-x.

64. Perros F, Gunther S, Ranchoux B, Godinas L, Antigny F, Chaumais MC, et al. Mitomycin-Induced Pulmonary Veno-Occlusive Disease: Evidence From Human Disease and Animal Models. Circulation. 2015; 132: 834-47. doi:10.1161/CIRCULATIONAHA.115.014207.

65. Schaefer CJ, Ruhrmund DW, Pan L, Seiwert SD, Kossen K. Antifibrotic activities of pirfenidone in animal models. European respiratory review : an official journal of the European Respiratory Society. 2011; 20: 85-97. doi:10.1183/09059180.00001111.

66. Di Sario A, Bendia E, Svegliati Baroni G, Ridolfi F, Casini A, Ceni E, et al. Effect of pirfenidone on rat hepatic stellate cell proliferation and collagen production. Journal of hepatology. 2002; 37: 584-91.

67. Hewitson TD, Kelynack KJ, Tait MG, Martic M, Jones CL, Margolin SB, et al. Pirfenidone reduces in vitro rat renal fibroblast activation and mitogenesis. Journal of nephrology. 2001; 14: 453-60.

68. Lin $\mathrm{X}, \mathrm{Yu} \mathrm{M}, \mathrm{Wu} \mathrm{K}$, Yuan $\mathrm{H}$, Zhong $\mathrm{H}$. Effects of pirfenidone on proliferation, migration, and collagen contraction of human Tenon's fibroblasts in vitro. Investigative ophthalmology \& visual science. 2009; 50: 3763-70. doi:10.1167/iovs.08-2815

69. Walter RF, Zarogoulidis P, Mairinger FD, Werner R, Darwiche K, Zarogoulidis $\mathrm{K}$, et al. Cell viability of fibroblasts to pifenidone and sirolimus: a future concept for drug eluting stents. International journal of pharmaceutics. 2014; 466: 38-43. doi:10.1016/j.ijpharm.2014.03.003.

70. Nakayama S, Mukae H, Sakamoto N, Kakugawa T, Yoshioka S, Soda H, et al. Pirfenidone inhibits the expression of HSP47 in TGF-beta1-stimulated human lung fibroblasts. Life sciences. 2008; 82: 210-7. doi:10.1016/j.lfs.2007.11.003.

71. Grattendick KI, Nakashima JM, Feng L, Giri SN, Margolin SB. Effects of three anti-TNF-alpha drugs: etanercept, infliximab and pirfenidone on release of TNF-alpha in medium and TNF-alpha associated with the cell in vitro. Inter$\begin{array}{llll}\text { national immunopharmacology. } & \text { 2008; } & \text { 6: }\end{array}$ doi:10.1016/j.intimp.2008.01.013.

72. Zarogoulidis P, Lampaki S, Yarmus L, Kioumis I, Pitsiou G, Katsikogiannis N, et al. Interleukin-7 and interleukin-15 for cancer. Journal of Cancer. 2014; 5: 765-73. doi:10.7150/jca.10471.

73. Zarogoulidis P, Yarmus L, Darwiche K, Walter R, Huang H, Li Z, et al. Interleukin-6 cytokine: a multifunctional glycoprotein for cancer. Immunome research. 2013; 9: 16535. doi:10.1186/2090-5009-9-1.

74. Zarogoulidis P, Katsikogianni F, Tsiouda T, Sakkas A, Katsikogiannis N, Zarogoulidis K. Interleukin-8 and interleukin-17 for cancer. Cancer investigation. 2014; 32: 197-205. doi:10.3109/07357907.2014.898156.

75. Bissler JJ, Kingswood JC, Radzikowska E, Zonnenberg BA, Frost M, Belousova E, et al. Everolimus for renal angiomyolipoma in patients with tuberous sclerosis complex or sporadic lymphangioleiomyomatosis: extension of a randomized controlled trial. Nephrology, dialysis, transplantation : official publication of the European Dialysis and Transplant Association - European Renal Association. 2015. doi:10.1093/ndt/gfv249.

76. Generali D, Venturini S, Rognoni C, Ciani O, Pusztai L, Loi S, et al. A network meta-analysis of everolimus plus exemestane versus chemotherapy in the first- and second-line treatment of estrogen receptor-positive metastatic breast cancer. Breast cancer research and treatment. 2015; 152: 95-117. doi:10.1007/s10549-015-3453-9.

77. Hortobagyi GN. Everolimus plus exemestane for the treatment of advanced breast cancer: a review of subanalyses from BOLERO-2. Neoplasia. 2015; 17: 279-88, doi:10.1016/j.neo.2015.01.005.

78. Beck JT, Mantooth R. A Case of Disease Improvement after Treatment with Everolimus plus Exemestane in a Patient with Hormone Receptor-Positive Metastatic Breast Cancer with Bone Metastases. Case reports in oncology. 2015; 8: 101-5. doi:10.1159/000375119.

79. Formica RN, Jr., Lorber KM, Friedman AL, Bia MJ, Lakkis F, Smith JD, et al. The evolving experience using everolimus in clinical transplantation. Transplantation proceedings. 2004; 36: 495S-9S. doi:10.1016/j.transproceed.2004.01.015.

80. Jerusalem G, Rorive A, Collignon J. [The drug of the month: everolimus (Afinitor) for the treatment of metastatic breast cancer]. Revue medicale de Liege. 2014; 69: 510-7.

81. Eisen HJ, Tuzcu EM, Dorent R, Kobashigawa J, Mancini D, Valantine-von Kaeppler HA, et al. Everolimus for the prevention of allograft rejection and vasculopathy in cardiac-transplant recipients. The New England journal of medicine. 2003; 349: 847-58. doi:10.1056/NEJMoa022171.

82. Burke SE, Kuntz RE, Schwartz LB. Zotarolimus (ABT-578) eluting stents. Advanced drug delivery reviews. 2006; 58: 437-46. doi:10.1016/j.addr.2006.01.021.

83. Seidel ER, Ragan VL. Inhibition by rapamycin of ornithine decarboxylase and epithelial cell proliferation in intestinal IEC- 6 cells in culture. British journal of pharmacology. 1997; 120: 571-4. doi:10.1038/sj.bjp.0700936.

84. Javier AF, Bata-Csorgo Z, Ellis CN, Kang S, Voorhees JJ, Cooper KD. Rapamycin (sirolimus) inhibits proliferating cell nuclear antigen expression and blocks cell cycle in the G1 phase in human keratinocyte stem cells. The Journal of clinical investigation. 1997; 99: 2094-9. doi:10.1172/JCI119382.

85. Motylewska E, Lawnicka H, Kowalewicz-Kulbat M, Sicinska P, Niedziela A, Melen-Mucha G, et al. Interferon alpha and rapamycin inhibit the growth of pheochromocytoma PC12 line in vitro. Endokrynologia Polska. 2013; 64: 368-74. doi:10.5603/EP.2013.0020
86. Jin $\mathrm{C}$, Zhao $\mathrm{Y}, \mathrm{Yu}, \mathrm{L}, \mathrm{Xu}, \mathrm{S}, \mathrm{Fu}$ G. MicroRNA-21 mediates the rapamycin-induced suppression of endothelial proliferation and migration. FEBS letters. 2013; 587: 378-85. doi:10.1016/j.febslet.2012.12.021

87. Obata JE, Nakamura T, Kitta $Y$, Saito $Y$, Sano $K$, Fujioka D, et al. In-stent restenosis is inhibited in a bare metal stent implanted distal to a sirolimus-eluting stent to treat a long de novo coronary lesion with small distal vessel diameter. Catheterization and cardiovascular interventions : official journal of the Society for Cardiac Angiography \& Interventions. 2013; 82: E777-87. doi:10.1002/ccd.24841.

88. Qiu H, Hu XY, Luo T, Xu B, Xie J, Hu X, et al. Short-term safety and effects of a novel fully bioabsorable poly-L-lactic acid sirolimus-eluting stents in porcine coronary arteries. Chinese medical journal. 2013; 126: 1183-5.

89. Deng J, Han Y, Sun M, Tao J, Yan C, Kang J, et al. Nanoporous CREG-eluting stent attenuates in-stent neointimal formation in porcine coronary arteries. PloS one. 2013; 8: e60735. doi:10.1371/journal.pone.0060735.

90. De Luca G, Dirksen MT, Spaulding C, Kelbaek H, Schalij M, Thuesen L, et al. Meta-analysis comparing efficacy and safety of first generation drug-eluting stents to bare-metal stents in patients with diabetes mellitus undergoing primary percutaneous coronary intervention. The American journal of cardiology. 2013; 111: 1295-304. doi:10.1016/j.amjcard.2013.01.281.

91. Tada T, Byrne RA, Schuster T, Cuni R, Kitabata H, Tiroch K, et al. Early vascular healing with rapid breakdown biodegradable polymer sirolimus-eluting versus durable polymer everolimus-eluting stents assessed by optical coherence tomography. Cardiovascular revascularization medicine : including molecular interventions. 2013; 14: 84-9. doi:10.1016/j.carrev.2012.12.003.

92. Kim U, Park JS, Lee SH, Shin DG, Kim YJ. Seven-year clinical outcomes of sirolimus-eluting stent versus bare-metal stent: a matched analysis from a real world, single center registry. Journal of Korean medical science. 2013; 28: 396-401. doi:10.3346/jkms.2013.28.3.396.

93. Mischie AN, Nazzaro MS, Fiorilli R, De Felice F, Musto C, Confessore P, et al. Head-to-head comparison of sirolimus-eluting stent versus bare metal stent evaluation of the coronary endothelial dysfunction in the same patient presenting with multiple coronary artery lesions: the CREDENTIAL study. Catheterization and cardiovascular interventions : official journal of the Society for Cardiac Angiography \& Interventions. 2013; 82: E184-91. doi: $10.1002 /$ ccd. 24844

94. Gao RL, Xu B, Lansky AJ, Yang YJ, Ma CS, Han YL, et al. A randomised comparison of a novel abluminal groove-filled biodegradable polymer sirolimus-eluting stent with a durable polymer everolimus-eluting stent: clinical and angiographic follow-up of the TARGET I trial. EuroIntervention : journal of EuroPCR in collaboration with the Working Group on Interventional Cardiology of the European Society of Cardiology. 2013; 9: 75-83. doi:10.4244/EIJV9I1A12.

95. Lemos PA, Bienert I. The Supralimus sirolimus-eluting stent. Expert review of medical devices. 2013. 10: 295-300 doi:10.1586/erd.12.91.

96. Abhyankar A, Prajapati J, Reddy S, Reddy S. Early vascular healing with biodegradable polymer coated sirolimus-eluting coronary stent implantation: assessed by optical coherence tomography results at 4-month follow-up. Minerva cardioangiologica. 2013; 61: 313-22.

97. Ko YG, Shin DH, Kim JS, Kim BK, Choi D, Hong MK, et al. Comparison of neointimal hyperplasia and peri-stent vascular remodeling after implantation of everolimus-eluting versus sirolimus-eluting stents: intravascular ultrasound results from the EXCELLENT study. The international journal of cardiovascular imaging. 2013; 29: 1229-36. doi:10.1007/s10554-013-0199-5.

98. Habib A, Karmali V, Polavarapu R, Akahori H, Pachura K, Finn AV. Metformin impairs endothelialization after placement of newer generation drug

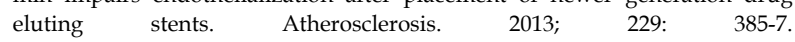
doi:10.1016/j.atherosclerosis.2013.06.001.

99. Iwata $\mathrm{Y}$, Fujimoto $\mathrm{Y}$, Morino $\mathrm{T}$, Sugimoto $\mathrm{K}$, Ohkubo $\mathrm{K}$, Kadohira T, et al. Effects of stem cell mobilization by granulocyte colony-stimulating factor on endothelial function after sirolimus-eluting stent implantation: a double-blind, randomized, placebo-controlled clinical trial. American heart journal. 2013; 165: 408-14. doi:10.1016/j.ahj.2012.12.010.

100. Erdim R, Helvacioglu F, Gormez S, Karabay KO, Aytekin V. Two-Year Follow-up of Sirolimus-Eluting Stents versus Paclitaxel-Eluting Stents in Acute Myocardial Infarction. The International journal of angiology : official publication of the International College of Angiology, Inc. 2012; 21: 53-8. doi:10.1055/s-0032-1302436.

101. Tarantini G, Barioli A, Facchin M, Frigo AC, Napodano M, Buja P, et al. Six-year clinical outcomes of first-generation drug-eluting stents: a propensity-matched analysis. Coronary artery disease. 2013; 24: 440-8. doi:10.1097/MCA.0b013e328362b2ab.

102. Hsieh IC, Hsieh MJ, Chang SH, Wang CY, Lee CH, Lin FC, et al. Acute and long-term outcomes of ostial stentings among bare-metal stents, sirolimus-eluting stents, and paclitaxel-eluting stents. Coronary artery disease. 2013; 24: 224-30. doi:10.1097/MCA.0b013e32835c8fce.

103. Heldman AW, Cheng L, Jenkins GM, Heller PF, Kim DW, Ware M, Jr., et al. Paclitaxel stent coating inhibits neointimal hyperplasia at 4 weeks in a porcine model of coronary restenosis. Circulation. 2001; 103: 2289-95.

104. Bharadwaj R, Yu H. The spindle checkpoint, aneuploidy, and cancer. Oncogene. 2004; 23: 2016-27. doi:10.1038/sj.onc.1207374.

105. Brito DA, Yang Z, Rieder CL. Microtubules do not promote mitotic slippage when the spindle assembly checkpoint cannot be satisfied. The Journal of cell biology. 2008; 182: 623-9. doi:10.1083/jcb.200805072. 
106. Jordan MA, Wilson L. Microtubules as a target for anticancer drugs. Nature reviews Cancer. 2004; 4: 253-65. doi:10.1038/nrc1317.

107. Ganguly A, Yang H, Cabral F. Paclitaxel-dependent cell lines reveal a novel drug activity. Molecular cancer therapeutics. 2010; 9: 2914-23. doi:10.1158/1535-7163.MCT-10-0552.

108. Lowe J, Li H, Downing KH, Nogales E. Refined structure of alpha beta-tubulin at 3.5 A resolution. Journal of molecular biology. 2001; 313: 1045-57. doi:10.1006/jmbi.2001.5077.

109. Cardoso PF, Snell GI, Hopkins P, Sybrecht GW, Stamatis G, Ng AW, et al. Clinical application of airway bypass with paclitaxel-eluting stents: early results. The Journal of thoracic and cardiovascular surgery. 2007; 134: 974-81. doi:10.1016/j.jtcvs.2007.05.040.

110. Harjai KJ, Kondareddy S, Pinkosky B, Harjai N, Orshaw P, Boura J. Everolimus-eluting stents versus sirolimus- or paclitaxel-eluting stents: two-year results from the Guthrie Health Off-Label Stent (GHOST) registry. Journal of $\begin{array}{llll}\text { interventional } & \text { cardiology. } & 2013 ; & 26:\end{array}$ doi:10.1111/j.1540-8183.2013.12016.x

111. Dake MD, Ansel GM, Jaff MR, Ohki T, Saxon RR, Smouse HB, et al. Sustained safety and effectiveness of paclitaxel-eluting stents for femoropopliteal lesions: 2-year follow-up from the Zilver PTX randomized and single-arm clinical studies. Journal of the American College of Cardiology. 2013; 61: 2417-27. doi:10.1016/j.jacc.2013.03.034

112. Wohrle J, Brodie B, Witzenbichler B, Dudek D, Kornowski R, Metzger C, et al. Impact of bivalirudin and paclitaxel-eluting stents on outcomes in patients undergoing primary percutaneous coronary intervention of the left anterior descending artery. The American journal of cardiology. 2013; 112: 753-60. doi:10.1016/j.amjcard.2013.05.006.

113. Seo JB, Kang SH, Hur SH, Park KW, Youn TJ, Park JS, et al. Randomized trial comparing the efficacy between different types of paclitaxel-eluting stents: the comparison of efficacy between COroflex PLEASe ANd Taxus stent (ECO-PLEASANT) randomized controlled trial. American heart journal. 2013; 165: 733-43. doi:10.1016/j.ahj.2013.02.009.

114. De la Torre Hernandez JM, Alfonso F, Sanchez Recalde A, Jimenez Navarro MF, Perez de Prado A, Hernandez F, et al. Comparison of paclitaxel-eluting stents (Taxus) and everolimus-eluting stents (Xience) in left main coronary artery disease with 3 years follow-up (from the ESTROFA-LM registry). The American journal of cardiology. 2013; 111: 676-83. doi:10.1016/j.amjcard.2012.11.019.

115. Shi J, Lv Y, Yu L, Zhang B, Zhang X, Fan C, et al. Interest of a new biodegradable stent coated with paclitaxel on anastomotic wound healing after biliary reconstruction. European journal of gastroenterology \& hepatology. 2013; 25: 1415-23. doi:10.1097/MEG.0b013e328361eb51.

116. Agwuh KN, MacGowan A. Pharmacokinetics and pharmacodynamics of the tetracyclines including glycylcyclines. The Journal of antimicrobial chemotherapy. 2006; 58: 256-65. doi:10.1093/jac/dkl224.

117. Dursun D, Kim MC, Solomon A, Pflugfelder SC. Treatment of recalcitrant recurrent corneal erosions with inhibitors of matrix metalloproteinase-9, doxycycline and corticosteroids. American journal of ophthalmology. 2001; 132: $8-13$

118. Smits PC, Hofma S, Togni M, Vazquez N, Valdes M, Voudris V, et al. Abluminal biodegradable polymer biolimus-eluting stent versus durable polymer everolimus-eluting stent (COMPARE II): a randomised, controlled, $\begin{array}{lllr}\text { non-inferiority trial. } & \text { Lancet. } & \text { 2013; } & \text { 381: }\end{array}$ doi:10.1016/S0140-6736(12)61852-2.

119. Park KW, Kang SH, Velders MA, Shin DH, Hahn S, Lim WH, et al. Safety and efficacy of everolimus- versus sirolimus-eluting stents: a systematic review and meta-analysis of 11 randomized trials. American heart journal. 2013; 165: 241-50 e4. doi:10.1016/j.ahj.2012.08.007.

120. Kitabata H, Loh JP, Sardi GL, Badr S, Dvir D, Barbash IM, et al. Comparison of long-term outcomes between everolimus-eluting and sirolimus-eluting stents in small vessels. The American journal of cardiology. 2013; 111: 973-8. doi:10.1016/j.amjcard.2012.12.015.

121. Moreno R, Garcia E, Teles R, Rumoroso JR, Cyrne Carvalho H, Goicolea FJ, et al. Randomized comparison of sirolimus-eluting and everolimus-eluting coronary stents in the treatment of total coronary occlusions: results from the chronic coronary occlusion treated by everolimus-eluting stent randomized trial. Circulation Cardiovascular interventions. 2013; 6: 21-8. doi:10.1161/CIRCINTERVENTIONS.112.000076.

122. Kozuma K, Kimura T, Kadota K, Suwa S, Kimura K, Iwabuchi M, et al. Angiographic findings of everolimus-eluting as compared to sirolimus-eluting stents: angiographic sub-study from the Randomized Evaluation of Sirolimus-eluting versus Everolimus-eluting stent Trial (RESET). Cardiovascular intervention and therapeutics. 2013; 28: 344-51. doi:10.1007/s12928-013-0179-7.

123. Tandjung K, Sen H, Lam MK, Basalus MW, Louwerenburg JH, Stoel MG, et al. Clinical outcome following stringent discontinuation of dual antiplatelet therapy after 12 months in real-world patients treated with second-generation zotarolimus-eluting resolute and everolimus-eluting Xience V stents: 2-year follow-up of the randomized TWENTE trial. Journal of the American College of Cardiology. 2013; 61: 2406-16. doi:10.1016/j.jacc.2013.04.005.

124. Kim SJ, Lee H, Cho JM, Park CB, Kim W, Kato K, et al. Comparison of zotarolimus-eluting stent and everolimus-eluting stent for vascular healing response: serial 3-month and 12-month optical coherence tomography study. Coronary artery disease. 2013; 24: 431-9. doi:10.1097/MCA.0b013e328362b2e7.

125. Park KW, Lee JM, Kang SH, Ahn HS, Yang HM, Lee HY, et al. Safety and efficacy of second-generation everolimus-eluting Xience $\mathrm{V}$ stents versus zo- tarolimus-eluting resolute stents in real-world practice: patient-related and stent-related outcomes from the multicenter prospective EXCELLENT and RESOLUTE-Korea registries. Journal of the American College of Cardiology. 2013; 61: 536-44. doi:10.1016/j.jacc.2012.11.015.

126. Xu B, Yang Y, Yuan Z, Du Z, Wong SC, Genereux P, et al. Zotarolimus- and paclitaxel-eluting stents in an all-comer population in China: the RESOLUTE China randomized controlled trial. JACC Cardiovascular interventions. 2013; 6: 664-70. doi:10.1016/j.jcin.2013.03.001.

127. Van den Branden BJ, Teeuwen K, Koolen JJ, van der Schaaf RJ, Henriques JP, Tijssen JG, et al. Primary Stenting of Totally Occluded Native Coronary Arteries III (PRISON III): a randomised comparison of sirolimus-eluting stent implantation with zotarolimus-eluting stent implantation for the treatment of total coronary occlusions. EuroIntervention : journal of EuroPCR in collaborawith the Working Group on Interventional Cardiology of the European Society of Cardiology. 2013; 9: 841-53. doi:10.4244/EIJV9I7A138.

128. Choong CK, Haddad FJ, Gee EY, Cooper JD. Feasibility and safety of airway bypass stent placement and influence of topical mitomycin $C$ on stent patency. The Journal of thoracic and cardiovascular surgery. 2005; 129: 632-8. doi:10.1016/j.jtcvs.2004.07.062.

129. Coppit G, Perkins J, Munaretto J, Nielsen R, McKinney L, Ulnick K. The effects of mitomycin-C and stenting on airway wound healing after laryngotracheal reconstruction in a pig model. International journal of pediatric otorhinolaryngology. 2000; 53: 125-35.

130. Sztano B, Torkos A, Rovo L. The combined endoscopic management of congenital laryngeal web. International journal of pediatric otorhinolaryngology. 2010; 74: 212-5. doi:10.1016/j.ijporl.2009.11.007.

131. Uzomefuna V, Glynn F, Al-Omari B, Hone S, Russell J. Transnasal endoscopic repair of choanal atresia in a tertiary care centre: a review of outcomes. International journal of pediatric otorhinolaryngology. 2012; 76: 613-7. doi:10.1016/j.ijporl.2012.01.033.

132. Carter JM, Lawlor C, Guarisco JL. The efficacy of mitomycin and stenting in choanal atresia repair: a 20 year experience. International journal of pediatric otorhinolaryngology. 2014; 78: 307-11. doi:10.1016/j.ijporl.2013.11.031.

133. Kim H, Park JH, Chung H, Han DH, Kim DY, Lee CH, et al. Clinical features and surgical outcomes of congenital choanal atresia: factors influencing success from 20-year review in an institute. American journal of otolaryngology. 2012; 33: 308-12. doi:10.1016/j.amjoto.2011.08.010.

134. Choong CK, Phan L, Massetti P, Haddad FJ, Martinez C, Roschak E, et al. Prolongation of patency of airway bypass stents with use of drug-eluting stents. The Journal of thoracic and cardiovascular surgery. 2006; 131: 60-4. doi:10.1016/j.jtcvs.2005.07.057.

135. Shah PL, Hopkinson NS. Bronchoscopic lung volume reduction for emphysema: where next? The European respiratory journal. 2012; 39: 1287-9. doi:10.1183/09031936.00217411.

136. Shah PL, Slebos DJ, Cardoso PF, Cetti EJ, Sybrecht GW, Cooper JD. Design of the exhale airway stents for emphysema (EASE) trial: an endoscopic procedure for reducing hyperinflation. BMC pulmonary medicine. 2011; 11: 1 . doi:10.1186/1471-2466-11-1.

137. Zhu GH, Ng AH, Venkatraman SS, Boey FY, Wee AL, Trasti SL, et al. A novel bioabsorbable drug-eluting tracheal stent. The Laryngoscope. 2011; 121: 2234-9. doi:10.1002/lary.22175.

138. Bang S, Jang SI, Lee SY, Baek YY, Yun J, Oh SJ, et al. Molecular mechanism of local drug delivery with Paclitaxel-eluting membranes in biliary and pancreatic cancer: new application for an old drug. Gastroenterology research and practice. 2015; 2015: 568981. doi:10.1155/2015/568981.

139. Christiansen EH, Jensen LO, Thayssen P, Tilsted HH, Krusell LR, Hansen KN, et al. Biolimus-eluting biodegradable polymer-coated stent versus durable polymer-coated sirolimus-eluting stent in unselected patients receiving percutaneous coronary intervention (SORT OUT V): a randomised non-inferiority trial. Lancet. 2013; 381: 661-9. doi:10.1016/S0140-6736(12)61962-X.

140. Lemos PA, Farooq V, Takimura CK, Gutierrez PS, Virmani R, Kolodgie F, et al. Emerging technologies: polymer-free phospholipid encapsulated sirolimus nanocarriers for the controlled release of drug from a stent-plus-balloon or a stand-alone balloon catheter. EuroIntervention : journal of EuroPCR in collaboration with the Working Group on Interventional Cardiology of the European Society of Cardiology. 2013; 9: 148-56. doi:10.4244/EIJV9I1A21.

141. Miyazaki T, Yamasaki N, Tsuchiya T, Matsumoto K, Takagi K, Nagayasu T. Airway stent insertion simulated with a three-dimensional printed airway model. The Annals of thoracic surgery. 2015; 99: e21-3. doi:10.1016/j.athoracsur.2014.10.021.

142. Barone-Rochette G, Machecourt J, Vanzetto G, Foote A, Quesada JL, Castelli C, et al. The favorable price evolution between bare metal stents and drug eluting stents increases the cost effectiveness of drug eluting stents. International journal of cardiology. 2013; 168: 1466-71. doi:10.1016/j.ijcard.2012.12.054

143. Shin HW, Nam CW, Kim H, Hur SH, Kim YN, Kim KB, et al. Zotarolimus-eluting stent-induced hypersensitivity pneumonitis. The Korean journal of internal medicine. 2013; 28: 108-11. doi:10.3904/ kjim.2013.28.1.108.

144. Rhew SH, Ahn Y, Cho EA, Kim MS, Jang SY, Lee KH, et al. A patient with repeated catastrophic multi-vessel coronary spasm after zotarolimus-eluting stent implantation. Korean circulation journal. 2013; 43: 48-53. doi:10.4070/kcj.2013.43.1.48.

145. Wang Z, Liu J, Wu K, Shen Y, Mao A, Li J, et al. Nitinol stents loaded with a high dose of antitumor 5-fluorouracil or paclitaxel: esophageal tissue responses in a porcine model. Gastrointestinal endoscopy. 2015; 82: 153-60 e1. doi:10.1016/j.gie.2015.02.034 
146. Chen W, Shen Y, Rong H, Lei L, Guo S. Development and application of a validated gradient elution HPLC method for simultaneous determination of 5 -fluorouracil and paclitaxel in dissolution samples of 5 -fluorouracil/paclitaxel-co-eluting stents. Journal of pharmaceutical and biomedical analysis. 2012; 59: 179-83. doi:10.1016/j.jpba.2011.10.005.

147. Lei L, Liu X, Shen YY, Liu JY, Tang MF, Wang ZM, et al. Zero-order release of 5-fluorouracil from PCL-based films featuring trilayered structures for stent application. European journal of pharmaceutics and biopharmaceutics : official journal of Arbeitsgemeinschaft fur Pharmazeutische Verfahrenstechnik eV. 2011; 78: 49-57. doi:10.1016/j.ejpb.2011.01.003.

148. Lei L, Liu X, Guo S, Tang M, Cheng L, Tian L. 5-Fluorouracil-loaded multilayered films for drug controlled releasing stent application: Drug release, microstructure, and ex vivo permeation behaviors. Journal of controlled release : official journal of the Controlled Release Society. 2010; 146: 45-53. doi:10.1016/j.jconrel.2010.05.017.

149. Hohenforst-Schmidt W, Zarogoulidis P, Darwiche K, Vogl T, Goldberg EP, Huang $\mathrm{H}$ et al. Intratumoral chemotherapy for lung cancer: re-challenge current targeted therapies. Drug Des Devel Ther. 2013 Jul 18;7:571-83. 